\title{
Pengaruh Peletakan Komposisi Warna Monochrome pada Bidang Window Display Terhadap Ketertarikan Pengunjung
}

\author{
Arsaika Widasati \\ 1. Program Studi Desain Interior, Fakultas Seni Rupa dan Desain, Institut Teknologi Bandung, Bandung, Indonesia \\ E-mail: arsaika@itb.ac.id
}

Informasi naskah:

Diterima

15 Januari 2021

Direvisi

30 Januari 2021

Disetujui terbit

20 Februari 2021

Diterbitkan

28 Februari 2021

\begin{abstract}
Window display is used to display products, provide information, attract visitors' attention then persuade visitors to approach and enter the store. Colour composition is the most attractive design element on window display to visitors' attention the most. This element is the easiest to identified by visitors. Monochromatic colour composition consists of one colour (hue) in various variants of its value and saturation. It is stated as an attractive and effective composition, thus it is widely used in window display spatial elements. This experiment investigated what kind of monochrome compositions that should be applied in window display that attract visitor the most. Window display schematic simulations with monochrome compositions are used as the stimulus of this research. The research subjects observed the simulation while filled out a set of online questionnaires. Results obtained from experiments prove that the monochrome schematic illustration which use a dark color (value 100) on the back wall and on the floor has the highest attractiveness to the visitors among other types of monochrome compositions.
\end{abstract}

Keywords: window display, color composition, attractiveness

\section{PENDAHULUAN}

Window display ialah salah satu bagian dari sebuah toko berupa bidang tembus pandang yang menarik pengunjung ${ }^{1)}$. Colborne ${ }^{2)}$ mendefinisikan window display sebagai sebuah presentasi yang dirancang, berupa pajangan dan ditempatkan pada jendela toko. Window display merupakan salah satu elemen toko yang paling efektif untuk menarik konsumen ke dalam toko ${ }^{3)}$. Window display merupakan sebuah mekanisme yang dapat mengubah pengunjung menjadi pelanggan serta merupakan bagian utuh dari sistem penjualan sebuah toko. Dengan begitu ada beberapa fungsi yang harus dipenuhi: menampilkan produk, mengenalkan toko (mengidentifikasi toko), membujuk pengunjung untuk mendekati toko dan mengundang konsumen untuk masuk ke dalam toko 1) 2) 3) 4). 
Berbagai elemen desain pada window display perlu dirancang berfungsi secara optimal dan dapat menarik perhatian pengunjung. Morgan ${ }^{5), 6)}$ mengklasifikasikan elemen desain window display menjadi lima jenis, diantaranya komposisi layout, komposisi bentuk, komposisi warna, komposisi cahaya serta komposisi grafis (tulisan dan ilustrasi).

Preliminary survey dengan cara membagikan kuesioner kepada 65 pengunjung pusat perbelanjaan di Bandung dilakukan untuk mengetahui elemen desain yang menarik pengunjung saat pertama kali melihat window display. Berdasarkan survey tersebut, dapat diketahui bahwa komposisi warna merupakan elemen window display yang paling menarik perhatian pengunjung (tabel 1). Sebuah window display yang berhasil umumnya menggunakan komposisi warna yang dapat menarik perhatian pengunjung. Pada sebuah window display yang efektif, warna merupakan elemen yang paling efisien untuk menghasilkan latar belakang bagi produk atau pajangan dan menciptakan suasana atau citra yang diinginkan.

Tabel 1. Elemen Window Display yang Paling Menarik Perhatian Pengunjung

\begin{tabular}{clc}
\hline No & \multicolumn{1}{c}{ Nama } & Persentase \\
\hline 1 & Komposisi layout/ pengaturan display & $7.3 \%$ \\
2 & Komposisi bentuk & $7.3 \%$ \\
3 & Komposisi warna & $46.4 \%$ \\
4 & Komposisi cahaya & $24.4 \%$ \\
5 & Komposisi grafis (tulisan dan ilustrasi) & $14.6 \%$ \\
\hline
\end{tabular}

Komposisi monochrome, analogous, complementary, split complementary, double complementary, triardic dan achromatic, merupakan beberapa tipe komposisi warna yang dapat diterapkan pada window display. Komposisi warna monochromatic merupakan komposisi warna yang hanya menggunakan satu warna dalam berbagai varian value dan saturation-nya. komposisi warna yang hanya monochrome yang hanya menggunakan satu warna terlihat sederhana, namun atraktif dan paling efektif sehingga digunakan pada window display ${ }^{6)}$. . Komposisi warna monochrome merupakan komposisi warna yang menghasilkan tekanan (tension) sehingga dapat memfokuskan perhatian seseorang tanpa menimbulkan gangguan pada mata (after image effect) akibat intensitas yang berlebihan ${ }^{7 \text { ). }}$

Layaknya sebuah ruang interior, window display memiliki enam bidang pembentuk ruang, yaitu: empat bidang dinding (walls), bidang lantai (floor) dan bidang langit-langit (ceiling). Penerapan warna monochrome di window display dapat digunakan pada tiga bidang dinding dan bidang lantai. Satu bidang dinding lainnya merupakan bidang transparan (kaca) dan satu bidang langit-langit yang umumnya tidak terlihat dengan jangkauan mata, sehingga kedua bidang tersebut dianggap tidak mempengaruhi hasil dari penelitian ini. Jika ditinjau dari fungsi utamanya, sebuah window display sebuah toko pakaian berfungsi untuk menarik perhatian pengunjung. Namun, window display dengan komposisi monochrome seperti apa yang dapat menarik perhatian pengunjung? Penelitian ini dilaksanakan dengan tujuan menggetahui komposisi monochrome yang memiliki daya tarik yang paling tinggi bagi pengunjung pusat perbelanjaan. 


\section{METODE}

Pada penelitian ini digunakan metode eksperimental. menggunakan pendekatan eksperimentatif simulatif. Metode eksperimentatif simulatif menggunakan simulasi digital dalam eksperimen, sehingga hasil dari penelitian ini bukan merupakan hasil yang akurat (100\%). Hal tersebut dikarenakan ada aspek-aspek pada kondisi nyata yang tidak dapat dimunculkan pada saat pelaksanaan.

\subsection{Subjek Penelitian/ Sample}

Pengunjung sebuah pusat pertokoan dapat berasal dari latar belakang sosial, ekonomi, pendidikan dan usia yang berbeda. Berdasarkan preliminary survey yang dilakukan pada dua pusat perbelanjaan di Bandung diperoleh data sebagai berikut:

Tabel 2. Usia Pengunjung yang Mengamati Window Display Toko Pakaian

\begin{tabular}{clc}
\hline No & \multicolumn{1}{c}{ Nama } & Persentase \\
\hline 1 & Komposisi layout/ pengaturan display & $7.3 \%$ \\
2 & Komposisi bentuk & $7.3 \%$ \\
3 & Komposisi warna & $46.4 \%$ \\
4 & Komposisi grafis (tulisan dan ilustrasi) & $14.6 \%$ \\
\hline
\end{tabular}

Berdasarkan tabel 2 dapat diketahui bahwa sebagian besar pengunjung berusia antara 21 hingga 31 tahun. Masing-masing kelompok karateristik masyarakat dapat memiliki persepsi dan perilaku yang berbeda terhadap tampilan window display. Oleh karena itu subyek penelitian dibatasi pada usia antara 21 hingga 31 tahun.

Pada penelitian ini, yang menjadi subyek penelitian ialah pengunjung pusat perbelanjaan. Jumlah pengunjung pusat perbelanjaan tidak dapat dipastikan, karena selalu terjadi perubahan jumlah pengunjung setiap harinya. Pada hari-hari tertentu, terutama apabila sedang diadakan sebuah acara (event), jumlah pengunjung jauh lebih banyak dibandingkan hari-hari biasa atau hari kerja. Bagi penelitian dengan jumlah sampel yang tidak tetap maka dapat digunakan metode iterasi ${ }^{8)}$. Dalam perhitungan melalui metode iterasi, jumlah sampel minimal yang menjadi responden eksperimen berjumlah 115 orang, oleh karena itu dalam penelitian ini jumlah sampel berjumlah 115 orang.

\subsection{Stimulus}

Stimulus yang digunakan pada penelitian ini terbagi menjadi tiga unsur. Berikut ini ialah penjelasan lebih lanjut mengenai stimulus yang akan digunakan:

\section{Window display}

Stimulus pada penelitian ini berupa ilustrasi skematik sebuah window display. Window display tersebut dimanipulasi berdasarkan window display toko fashion dengan target kalangan dewasa muda dan kondisi ekonomi menengah atas (diilustrasikan pada gambar 1). Window display yang digunakan merupakan window display datar (flat). Pemilihan window display tersebut dikarenakan objek - objek yang dipajang berwarna achromatic, sehingga jika warna bidang-bidang pembentuk ruang window display diganti dengan warna lain, objek 
- objek tersebut tetap netral atau tidak mengarah pada karakter tertentu. Window display yang digunakan dalam penelitian ini terdiri dari enam bidang pembentuk ruang. Namun hanya empat bidang pembentuk ruang yang berpengaruh pada penelitian ini, yaitu bidang dinding samping kiri, bidang dinding samping kanan, bidang dinding bagian belakang dan bidang lantai (floor). Dua bidang lainnya yaitu bidang langit-langit (ceiling) dan bidang dinding bagian depan tidak diperhitungkan. Window display yang diilustrasikan pada gambar 1 dimodifikasi agar dapat dimanipulasi sehingga menghasilkan kondisi window display yang sesuai dengan kebutuhan penelitian ini.

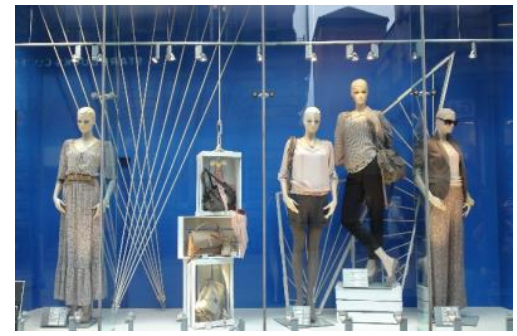

Gambar 1. Window display yang akan dimanipulasi

Sumber: msfitzella.wordpress.com

\section{Warna}

Dalam penelitian ini komposisi warna monochromatic akan diterapkan pada tiga bidang dinding dan bidang lantai window display. Komposisi warna monochromatic menggunakan satu hue dengan berbagai varian value dan chroma-nya. Warna merah digunakan pada penelitian ini karena memiliki intensitas yang cukup kuat sehingga dapat menarik perhatian seseorang yang melihatnya. Kobayashi ${ }^{9)}$ mengidentifikasi bahwa warna merah (R/V) merupakan warna yang melambangkan karakter masyarakat muda dengan gaya hidup modern dan casual.

Tabel 3. Value Warna Merah

\begin{tabular}{lll}
\hline No & Ilustrasi warna & \multicolumn{1}{c}{ Value } \\
\hline & & C: 0 \\
1 & & Y: 100 \\
& M: 100 \\
& K:0 \\
& & C: 0 \\
2 & Y: 10 \\
& M: $: 10$ \\
& K:0
\end{tabular}

Stimulus pada penelitian ini ditampilkan melalui simulasi digital, sehingga pemilihan warna merah didasarkan pada metode warna CYMK (Cyan Yellow Magenta Key). Dalam metode CYMK, merah (R/V) diperoleh melalui percampuran Yellow dan Magenta. Selanjutnya warna merah $(\mathrm{R} / \mathrm{V})$ yang akan digunakan dipilih berdasarkan besaran value- 
nya. Pada stimulus window display yang menggunakan komposisi monochromatic digunakan satu hue dengan value titik tertinggi dan titik terendah (tabel 3).

\subsection{Variabel}

\subsubsection{Variabel Kontrol}

Variabel kontrol merupakan variabel tetap yang terkait dengan variable independent. Variabel kontrol tidak mengalami perubahan atau tidak dimanipulasi. Variabel kontrol pada penelitian ini berupa simulasi window display. Sudut pandang frontal digunakan untuk mengamati window display pada penelitian ini.

\subsubsection{Variabel Independent}

Variabel independent merupakan kondisi yang dimanipulasi oleh peneliti sesuai dengan tujuan penelitiannya ${ }^{10}$. Variabel independent dimanipulasi berdasarkan kondisi variabel kontrol. Pada penelitian ini digunakan ilustrasi window display secara skematik (dua dimensional). Komposisi warna keempat bidang pembentuk ruang window display pada ilustrasi tersebut akan dimanipulasi berdasarkan stimulus warna yang telah dipaparkan sebelumnya. Komposisi warna yang diterapkan pada ilustrasi window display, antara lain:

1. Skema A (1 bidang gelap dan 3 bidang terang)

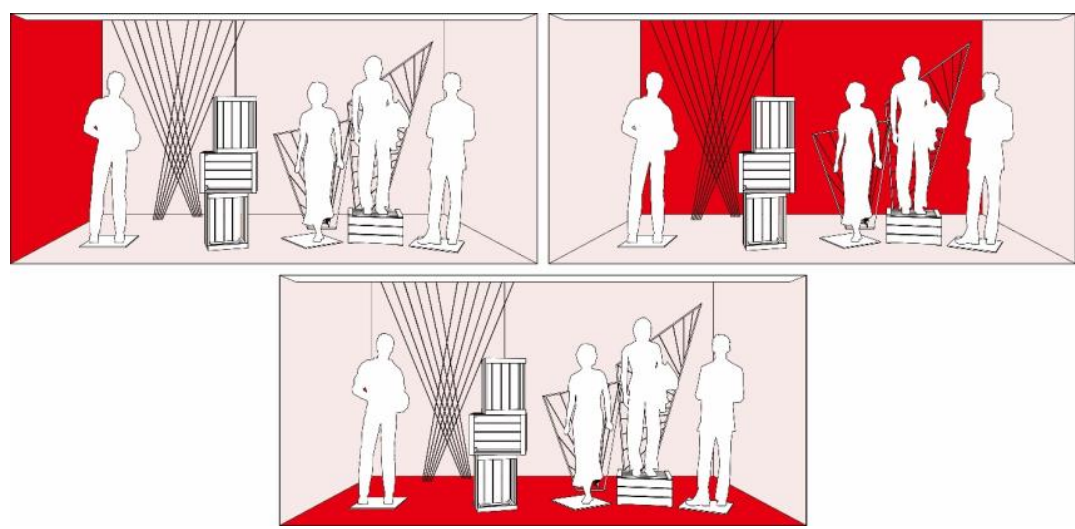

Gambar 2. Skema A1, A2, A3 (kiri atas, kanan atas, bawah)

2. Skema B ( 2 bidang gelap dan 2 bidang terang) 

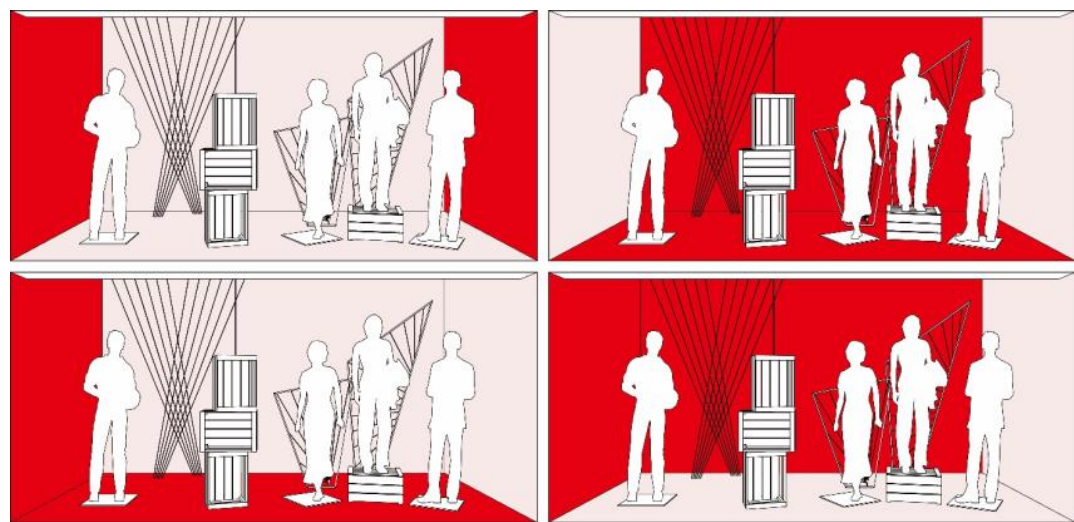

Gambar 3. Skema B1, B2, B3, B4 (kiri atas, kanan atas, kiri bawah, kanan bawah)

3. Skema C (3 bidang gelap dan 1 bidang terang)
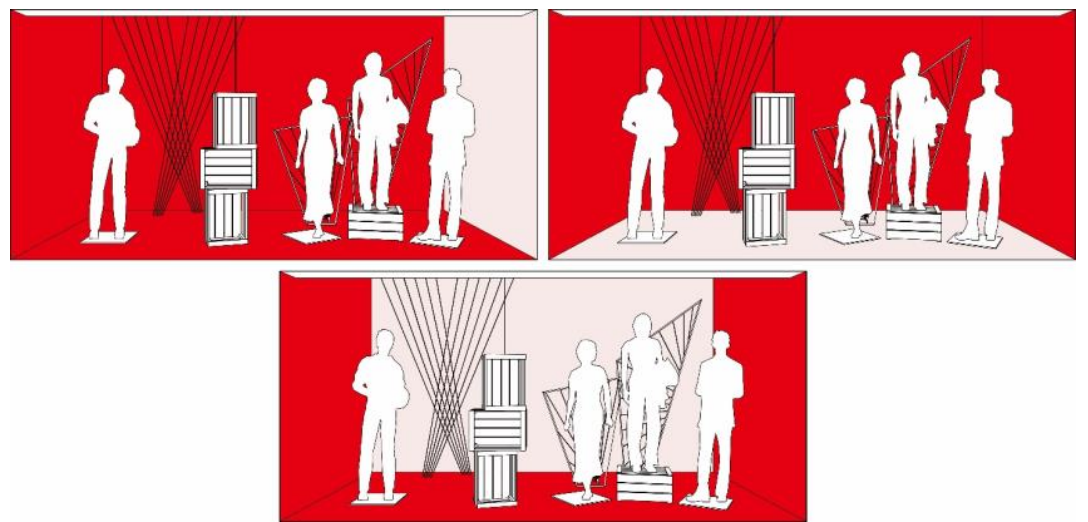

Gambar 4. Skema C1, C2, C3 (kiri atas, kanan atas, bawah)

\subsubsection{Variabel Dependent}

Variabel dependent merupakan penilaian yang dilakukan oleh subyek penelitian atau dikenal dengan istilah subject's scores ${ }^{10}$. Variabel dependent dipengaruhi oleh variabel independent. Pada penelitian ini variabel dependent yang digunakan ialah tingkat ketertarikan subyek penelitian pada saat melihat ilustrasi window display secara skematik pada monitor. Variabel dependent tersebut akan diukur melalui kuesioner (dalam skala likert) yang diberikan kepada subyek penelitian.

\subsection{Prosedur Penelitian}

Pada penelitian ini, subyek penelitian akan mengamati ilustrasi window display dua dimensional kemudian mengisi kuesioner. Ilustrasi dan kuesioner diakses melalui media survey online, sehingga eksperimen dapat dilakukan dimana saja. Eksperimen dilakukan dengan tujuan untuk mencari komposisi peletakan warna yang paling menarik bagi subyek penelitian. Tingkat ketertarikan subyek penelitian diukur melalui kuesioner yang menggunakan skala likert $(1-5)$. 
Eksperimen ini terdiri dari dua tahap. Pada tahap pertama subyek penelitian diberikan dua puluh ilustrasi skematik window display dengan menggunakan komposisi monochromatic. Dari tahap I-1 diseleksi tiga ilustrasi skematik window display (mewakili masing-masing kelompok skema A, B dan C) yang paling menarik bagi subyek penelitian. Selanjutnya dalam rentang waktu satu minggu dilakukan eksperimen tahap kedua. Pada tahap ini, subyek penelitian diberikan 3 ilustrasi skematik window display yang telah diseleksi melalui tahap sebelumnya. Kemudian, subyek penelitian memilih satu ilustrasi yang dianggap paling menarik.

\section{PEMBAHASAN DAN DISKUSI}

Pada eksperimen tahap pertama dan tahap kedua, subyek penelitian mengamati seluruh ilustrasi skematik melalui monitor komputer, sehingga posisi pengamatan subyek penelitian menghadap monitor komputer secara frontal. Tentu saja posisi pengamat mempengaruhi hasil eksperimen pada penelitian ini.

Berdasarkan eksperimen tahap pertama diperoleh tiga buah ilustrasi skematik window display dengan komposisi warna monochrome yang dianggap paling menarik oleh responden, yaitu ilustrasi skematik A2, B2 dan C2 (gambar 5). Skema - skema tersebut dianggap paling menarik dibandingkan tinggi dibandingkan ilustrasi skematik lain pada kelompoknya masing-masing. Ilustrasi yang dianggap paling tidak menarik pada kelompok A dan $\mathrm{C}$ ialah skema A1 dan C1. Responden berpendapat untuk kelompok skema B, tidak ada yang dianggap tidak menarik. Hal ini diakibatkan kelompok skema B memiliki komposisi yang seimbang antara bidang gelap dan terang.
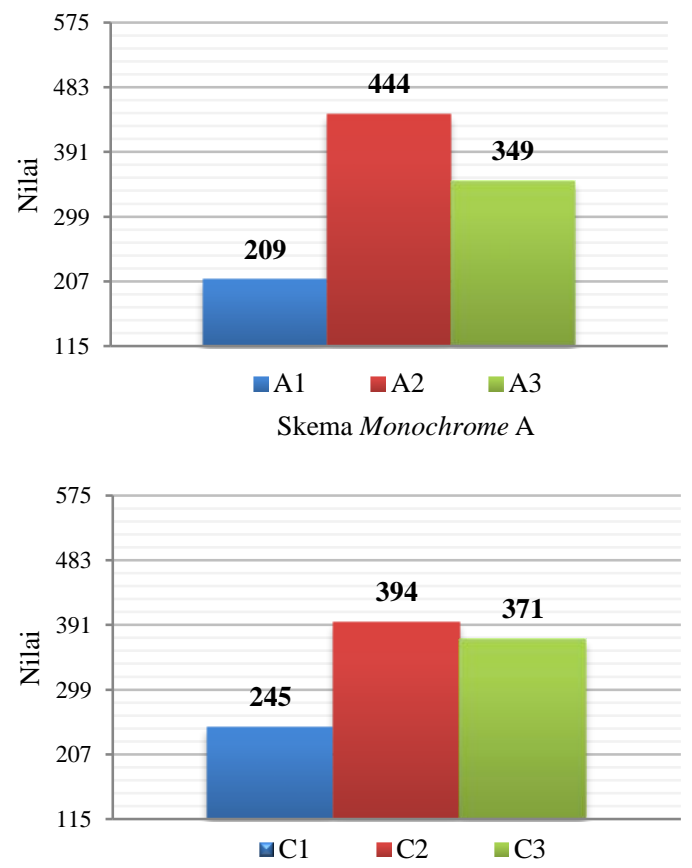

Skema Monochrome $\mathrm{C}$

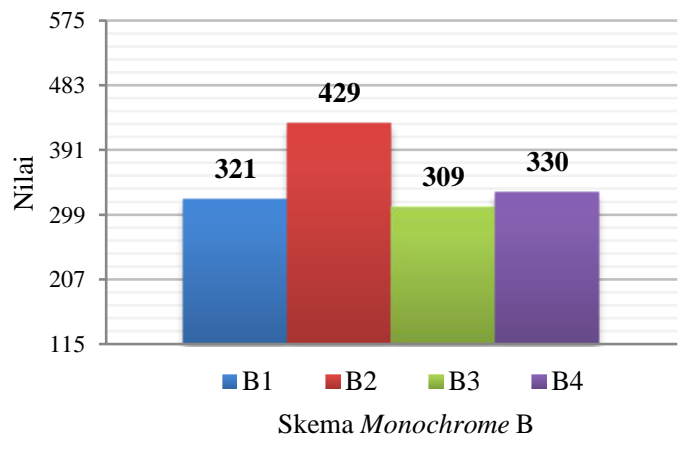

Keterangan nilai:

115 - 207 : Sangat tidak menarik

208 - 299 : Tidak menarik

300 - 391 : Agak menarik

$392-483$ : Menarik

484 - 575 : Sangat menarik 
Gambar 5. Hasil eksperimen tahap pertama

Ilustrasi skematik A2, B2 dan C2 lebih menarik perhatian subyek penelitian dibandingkan dengan skema lainnya. Ilustrasi skematik tersebut sama-sama menggunakan warna gelap (value 100) pada bidang dinding bagian belakang. Skema A2, B2 dan C2 kemudian digunakan sebagai stimulus di eksperimen tahap kedua.

Berdasarkan hasil eksperimen tahap kedua diketahui bahwa ilustrasi skematik B2 memiliki tingkat ketertarikan yang lebih tinggi dibandingkan ilustrasi skematik lain (gambar 6). Ilustrasi skematik B2 menggunakan warna gelap (value 100) pada bidang dinding bagian belakang dan bidang lantai. Dalam tahap eksperimen ini pun subyek penelitian mengamati seluruh ilustrasi skematik melalui monitor komputer, sehingga posisi pengamatan subyek penelitian menghadap monitor komputer tetap sama, secara frontal. Ketika mengamati ilustrasi skematik window display, bidang dinding bagian belakang dan bidang lantai window display merupakan bidang yang mendominasi perhatian dan mudah terlihat dibandingkan bidang yang lainnya karena termasuk pada daerah visual manusia secara horizontal dan secara vertikal.

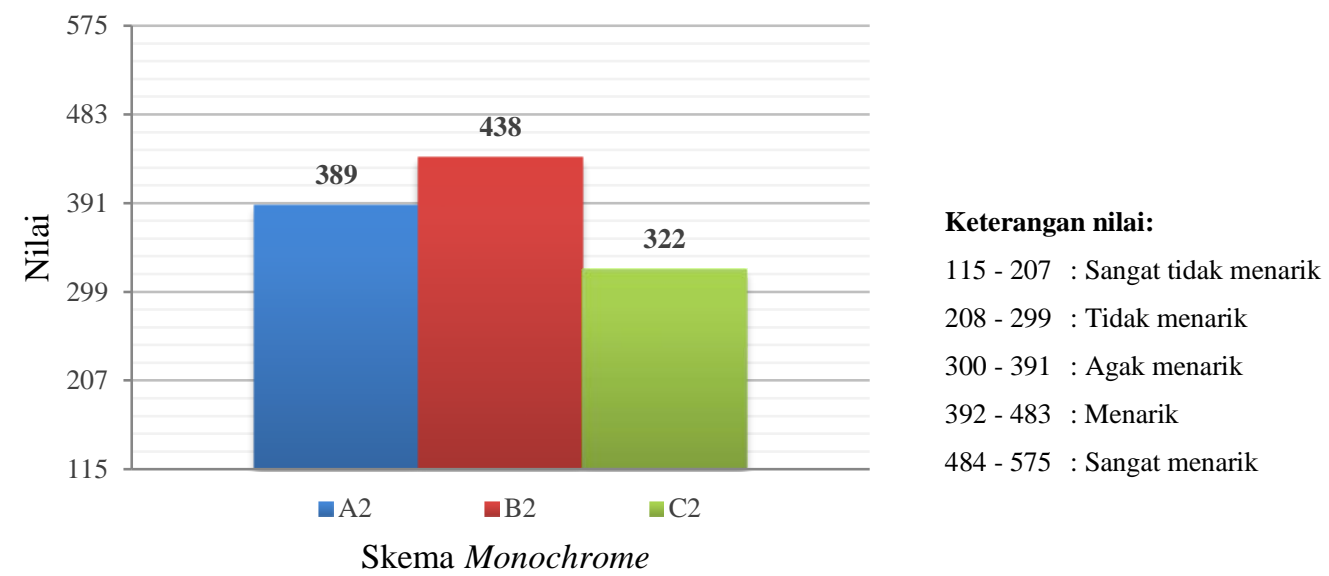

Gambar 6. Hasil eksperimen tahap kedua

Dengan menggunakan warna gelap (value 100) pada dinding bagian belakang dan bidang lantai dapat menambah ketertarikan subyek penelitian terhadap sebuah window display. Hal tersebut dikarenakan untuk menarik perhatian seseorang salah satunya dibutuhkan faktor kontras. Warna gelap (value 100) pada bidang dinding bagian belakang dan bidang lantai menghasilkan efek kontras terhadap produk yang dipajang. Oleh karena itu, ilustrasi skematik B2 merupakan ilustrasi skematik memiliki tingkat ketertarikan yang paling tinggi dibandingkan ilustrasi skematik lainnya.

\section{KESIMPULAN}

Berdasarkan hasil eksperimen tahap pertama diketahui bahwa ilustrasi skematik yang menggunakan warna gelap (value 100) di bidang dinding belakang pada komposisi 
monochrome memiliki tingkat ketertarikan yang lebih tinggi dibandingkan ilustrasi skematik lain pada kelompoknya masing-masing.

Hasil eksperimen tahap pertama tersebut diakibatkan oleh posisi pengamatan subyek penelitian secara frontal. Bidang dinding bagian belakang window display paling mendominasi perhatian dibandingkan bidang yang lainnya, karena termasuk pada daerah visual manusia secara horizontal. Selain itu, warna gelap di bidang dinding bagian belakang menimbulkan kesan kontras terhadap produk yang dipajang didepannya.

Berdasarkan hasil eksperimen tahap kedua diketahui bahwa ilustrasi skematik yang menggunakan warna gelap (value 100) di bidang dinding bagian belakang dan di bidang lantai pada komposisi monochrome memiliki tingkat ketertarikan yang lebih tinggi dibandingkan ilustrasi skematik komposisi monochrome lainnya.

Hasil penelitian ini akan lebih sempurna bila dilakukan eksperimen secara nyata, tanpa melalui manipulasi digital. Selain itu, jumlah sampel yang digunakan dapat diteliti berjumlah lebih banyak dan sampel dapat berasal dari kalangan usia lainnya, karena pada penelitian ini jumlah sampel yang digunakan belum begitu banyak dan secara acak hanya berasal dari kalangan dewasa muda yang tidak dipertimbangkan faktor latar belakang kebudayaannya.

\section{TERIMA KASIH}

Peneliti mengucapkan terima kasih kepada seluruh responden penelitian, Program Studi Desain Interior ITB, serta seluruh pihak yang membantu terlaksananya penelitian ini.

\section{DAFTAR PUSTAKA}

1) Mun, David. 1981. Shops : A Manual of Planning and Design. London: The Architectural Press.

2) Ti, Chihmin. 2009. The Effect of Window Display Setting and Background Music on Consumers' Mental Imagery, Arousal Response, Attitude and Approach Avoidance Behavior. Master Thesis: Oregon State University.

3) Pames, Louis Dr. 1948. Planning the Store that Pay. USA : F. W. Dodge Corporation.

4) Mesher, Lynne. 2010. Basics Interior Design : Retail Design. Lausanne - Switzerland: Ava Publishing.

5) Morgan, Tony. 2008. Visual Merchandising - Window and In-Store Displays for Retail. London: Laurence King Publishing.

6) Morgan, Tony. 2010. Window Display - New Merchandising. London: Laurence King Publishing.

7) Hasle, Albert O. 1968. The Use of Color in Interior. NewYork - USA: McGraw-Hill, Inc.

8) Widasari, Arsyana. 2011. Penerapan Experiental Marketing dan Brand Equity dalam Menciptakan Customer Trust Pada Breadtalk - Cihampelas Walk Bandung. Tesis Magister Manajemen: Universitas Padjadjaran. 
9) Kobayashi. Shigenobu, 1990. Color Image Scale. Tokyo - Japan: Kodansha, Ltd.

10) Greene, Judith et al. 1998. Methodology Handbook Part 2 - Experimental Research Designs. Norwich - UK: Page Bros. 